\title{
RESPONSE OF ECONOMIC DIVERSIFICATION TO GENDER INEQUALITY: EVIDENCE FROM NIGERIA
}

\author{
Nkechinyere Uwajumogu ${ }^{1}$, Ebele Nwokoye ${ }^{2}$, Innocent Ogbonna ${ }^{3}$, Mgbodichimma Okoro $^{1}$ \\ ${ }_{1}$ Department of Economics \& Development Studies, Alex Ekwueme Federal University, Ndufu-Alike, Ikwo, Ebonyi \\ State, Nigeria \\ ${ }_{2}$ Department of Economics, Nnamdi Azikiwe University, Awka, Anambra State, Nigeria \\ ${ }_{3}$ Department of Economics, Ebonyi State University, Ebonyi State, Nigeria
}

\begin{abstract}
Purpose: The danger inherent in anchoring the growth prospects of an economy on a single product has long been established and for decades now, Nigeria has remained a mono-product economy with all her foreign exchange earning possibilities anchored only on oil revenue. The paper sought to investigate the imperatives of gender equality in expanding the economic base of Nigeria.

Methodology: Based on the assumption of increasing returns to scale for the manufacturing sector and constant returns to scale for the primary sector, it apparently follows that a country's manufacturing output will grow faster (or slower) than that of the rest of the world if it had an initial comparative advantage in manufacturing (or primary) sector as hypothesized by the Prebisch-Singer Hypothesis. Employing Engel-Granger and Error Correction Model in an endogenous growth framework were used in this study.
\end{abstract}

Main Findings: This study found that the existing gender inequality has negative effect on the drive to diversify the economy by reducing the potential pool of human capital and promoting gaps in opportunities.

Applications: These programmes will help on female self-employment, increased ratio of female to male labour force participation rate and a reduction in the ratio of female to male in vulnerable employment should be included in policy formulations.

Novelty/Originality: The efforts should be sustained that totally remove or reduce to their barest minimum all patriarchal tendencies that exploit the female gender and place them at unequal gender relations. It is also recommended that social institutions such as social protection mechanisms should be entrenched as an avenue to reduce the vulnerabilities faced by women.

Keywords: Diversification, Economic Growth, Gender Inequality, Gender Parity, Vulnerability.

JEL Classifications: J16, O1

\section{INTRODUCTION}

The danger inherent in anchoring the growth prospects of an economy on a single product has long been established and for decades now, Nigeria has remained a mono-product economy with all her foreign exchange earning possibilities anchored only on oil revenue. Oil export revenue constitutes more than $90 \%$ of foreign exchange earnings and the oil sector persists as the driver of the mono-product Nigerian economy. This sector is the life-wire of the economy and drives policy formulation and implementation as budgeting is highly dependent on revenue from the sector. This over dependence on oil is also a significant and contributory factor to the non-inclusive nature of the economy and has established the Dutch-disease syndrome in the Nigerian economy. Its dependence on earnings from only one primary export commodity (crude oil), which is susceptible to volatilities in commodity prices, greatly affects the size of its public revenue. More so, the growth in Nigeria's crude oil sector does not have positive spillover effects because of its poor linkages with other sectors of the economy.

As a result of recent drops in commodity prices, resource-intensive countries have not only experienced a decline in economic growth but have also adopted macroeconomic adjustments to cushion the effects of declining fiscal and export revenues (IMF, 2016). For instance, Economy Watch (2016) reported that Nigeria's real GDP growth which was $6.3 \%$ in 2014 fell drastically to a negative rate of $2.3 \%$ in 2016 ; its investment and saving rates

Corresponding Author: ${ }^{1}$ ketchyus@yahoo.com 
fell from 15.8 and $16.0 \%$ in 2014 to 13.6 and $10.8 \%$ in 2016 respectively; and its unemployment rate rose from $7.8 \%$ in 2014 to $12.1 \%$ in 2016 . The poor performances of these macroeconomic indicators prove the dominance of as well as Nigeria's fiscal dependence on oil as a sole driver of policy formulation and implementation because empirical evidences have proved that the recent decline in the fiscal and export revenue base of Nigeria is linked to the 2014 decline in oil prices in the world crude oil market. Hence Nigeria's declining real GDP growth rate, fiscal revenue, and domestic investment rate; and its growing unemployment and poverty rates, enunciate that some macroeconomic adjustments are required to boost output, export in the real sector, and fiscal revenues of the country. Thus, diversifying the economy is important for an all-inclusive and sustainable economic growth.

Economic diversification refers to a process by which a growing range of marketable outputs are produced by a country with the aim of breeding economic resilience, economic stability and economic security such that macroeconomic shocks attributed to changes in revenue streams are easily adjusted to. It is also the varying of income sources away from the domestic economic activities as a diversified economy is one which has different revenue sources which hence provides the economy with the ability for sustained economic growth since reliance on a particular source of revenue is discouraged. Several pillars of economic diversification open to Nigeria include investment in infrastructure; support for agriculture, providing linkages between producers and markets; as well as improving business and regulatory environment, human capital development, etc. Apart from being naturally endowed with natural resources, Nigeria is blessed with vigorous, virile and entrepreneurial human resource and included in its pool of human resource, is the unutilized capability of the women folk, hidden and shrouded by persistent, prevalent and endemic gender inequality.

It is a truism that economic expansion which is not engendered is endangered. Therefore, institutional arrangements and economic policies which encourage greater equality amongst people and between males and females are honest ways through which economic and social development can be attained. Gender presents the basic organizing rules of societies which direct the line of production, distribution and consumption therefore its understanding provides an opportunity for appreciating the opportunities, constraints and impacts of transformation as they affect both men and women (Aina, 2012). Gender equality involves the extension of equivalent opportunities to both men and women. It is a human right and identifies its application as an essential tool for economic progress and reducing poverty. Even though gender equality does not imply no difference between women and men, it implies that the two have equal worth, and consequently, should be accorded equal treatment (International Planned Parenthood Federation, 2017). The Nigerian society has been patriarchal even as it evolved from its traditional society and this is a major reason for the enormous attention placed on societal roles as gender assumes a sensitive matter in Nigeria's economic and social progress.

Gender inequality constrains the economic diversification process by reducing the potential pool of human capital (as it breeds gaps in opportunities such as education, labour force participation, etc); and by impeding development of new ideas thereby reducing the effectiveness, efficiency and efficacy of the nation's labour force as the pool of talents available to the nation (as entrepreneurs and employees) (Teignier, \& Cuberes, 2014). Evidences of gender inequality in Nigeria include unequal opportunities in placements into permanent employment; unequal opportunities in accessing credit facilities from financial houses; unequal opportunities in accessing education; domestic and workplace violence/sexual harassments against women; etc. This paper is therefore interested in ascertaining the extent to which economic diversification responds to gender inequality in Nigeria with the intent of submitting policy recommendations aimed at expanding Nigeria's vision towards economic diversification. This goal is apt owing to literature exposure on direct and indirect positive and multiplier effect of gender equality and women empowerment on economic growth as well as the costs of gender discrimination.

To this end, this paper is structured as follows: Section one has introduced the study, Section two contains a review of basic literature, Section three contains the research methods and procedures, Section four presents and discusses the results while Section five concludes the study and makes recommendations for policy preparations and implementations.

\section{LITERATURE REVIEW}

\subsection{REVIEW OF BASIC THEORIES}

Notable economists like Kuznet, Grossman, and Helpman have posited that one hallmark of economic growth is the ability to produce and supply diverse variety, quality and quantity of goods and services over a long period of time. Economic diversification is important because it reduces the vulnerability and volatilities that economies face, and this increases economic growth as low volatility is associated with higher output. Theories of economic 
diversification are scarce in economic literature but the Graham paradox, Prebisch-Singer hypothesis and the endogenous growth theory explain the need for countries to move away from subsistence/primary production to manufacturing and industrialization which further attract division of labour and specialization.

\section{A. Graham Paradox}

In line with the assertion that women constitute more than $50 \%$ percentage of farmers and raw material processors in Nigeria, as held by Global Entrepreneurship Monitor (2004) cited in Metu, Nwokoye, and Kalu (2015), this study appreciates the contributions of the Graham (1923) which highlights the problems associated with specializing in agriculture for a country is modeled to work in accordance with the Ricardian theory. The Graham Paradox incorporates the non-constancy of unit costs (and by extension, non-constancy of productivity) existing between different sectors of the economy, into the Ricardian theory. In specific terms, productivity in the manufacturing sector rises as unit costs fall with increasing output due to the benefits of economics of scale, while the unit costs of agricultural products increase with production. For a country with a comparative advantage in agriculture, specialization, according to Ricardian theory, decreases both productivity and the country's total output. Raffer (2004) asserts that even global output expectedly declines if the increase in global manufacturing output is not sustained.

\section{B. Prebisch-Singer Hypothesis (PSH)}

Prebisch (1950) and Singer (1950) formulated the Prebisch-Singer hypothesis (PSH) which emphasizes that economic growth cannot be based on primary products since world prices for primary tradable commodities relative to manufactured tradable commodities decline over time. Consequently, the ratio of export prices to import prices (that is the terms of trade) for developing countries, which are mostly heavily reliant on exports of primary commodities, declines as well.

According to Cuddington, Ludema, and Jayasuriya (2002), the decrease in the terms of trade is often explained by strong labour unions in industrialized countries which cause wages in the manufacturing sector of each business cycle to rise at a much higher rate than the equilibrium wage rate; this is often unsustainable and often results in unsustainable growth in overall output; monopoly often flourish in the manufacturing sector and this prevents technological advancement thereby resulting in lower prices; as income grows, demand for, and hence price of, primary commodities reduce hence demand for primary commodities exhibit less income elasticity; and technical progress in the manufacturing sector (especially one having a raw-material-saving strategy) causes slowgrowing demand for primary products.

In general, the Graham paradox and the PSH provide arguments in support of economic diversification (of output and export commodities) by explaining the disadvantage of being specialized in the agriculture (and by extension, the crude oil sector as is the case with Nigeria). In principle, these arguments can therefore serve as a rationale and as a theoretical justification for embarking on economic diversification.

\section{Endogenous Growth Theory}

The endogenous growth theory further emphasizes the importance of the type of production in which a country specializes, as the returns to scale depend on the sector (whether primary/extractive - agricultural and mining sectors or secondary - manufacturing sector). Structural models of economic development demonstrate that countries develop their output (export) structure from primary commodities (exports) into manufactured commodities (exports) in order to achieve sustained economic growth. Based on the assumption of increasing returns to scale for the manufacturing sector and constant returns to scale for the primary sector, it apparently follows that a country's manufacturing output will grow faster (or slower) than that of the rest of the world if it had an initial comparative advantage in manufacturing (or primary) sector as hypothesized by the PSH.

\subsection{THEORETICAL LINK BETWEEN GENDER INEQUALITY AND ECONOMIC DIVERSIFICATION}

According to Kazandjian, Kolovich, Kochlar and Newiak (2016), economic diversification strongly correlates with structural transformations which involve changes in the relative importance of significant components of the economy such as improved institutional quality and infrastructure; higher degree of globalization; changes in market structure, etc; shifts in the sectoral composition of economic activity as well as reduction in gender inequality. 
Accordingly, gender equality can enhance economic diversification through two major channels- human capital channel and resource allocation channel (Kazandjian, et al, 2016). The human capital channel enunciates that gender gap in education can reduce the pool of human capital and ultimately reduce the speed of adoption of technology and innovation. Similarly, gender inequality in labour force participation rate is likely to reduce the pool of talents and employable entrepreneurs. This in turn reduces a country's ability to create and execute new ideas: a critical ingredient for economic diversification.

Literature theorizes that gender inequality influences the direction of growth and economic growth which is an important determinant as well as a by-product of economic diversification. Gender inequality in education can affect economic growth by impacting negatively on female education, increasing the couples' fertility rate (substituting quantity for quality of children) thereby giving less inclination to human capital development for the next generation. Growth in female labor participation further has a direct effect on per capita gross domestic product (GDP) because resources, which were hitherto focused for subsistence production are re-focused on production for commerce. As Galor and Weil (1996) puts it, as capital intensity which accompanies economic growth increases, the relative wages of women also do. This further induces women desire for more education thereby decreasing the relative wage gap between women and men for future generations as well as increasing women's opportunity cost of labour supply and encouraging them to enter the labor market while foregoing child-rearing.

Boserup (1970) asserts that the men' privileged access to education leaves out women from the labor force during the early stage of development but as a nation proceeds along the path to development, women begin to gain access to education and employment hence, the postulation that there is a $U$-shaped relationship between female labour force participation and per capita income. Goldin (1990) interprets this $U$-shaped postulation as a strong income effect at the early stage and an overriding substitution effect at the afterward stage. Hence well-educated female human capital (in the absence of gender inequality), across occupations and industries can increase a country's GDP.

According to Braunstein (2011), the efficiency argument for gender equality articulates that leaving out women from education, employment, and other profitable prospects reduces the pool of potential workforce and entrepreneurs and deprives economies of potential productive assets. Gender inequality generally raises fertility, lowers the accumulated stock of human and material capital for the next generation, and restricts potentials in household productivity as well as potentials of economic diversification. The efficiency argument holds that the net effect of gender inequality is lower rates of per capita income growth.

\subsection{EMPIRICAL LITERATURE REVIEW}

Although there are a plethora of studies linking gender inequality with economic growth, empirical literatures linking gender inequality with economic diversification are fewer. Furthermore, fewer of these studies show negative impacts of gender gaps in education and employment on economic growth while the empirical evidences on positive effects of gender inequality on economic growth are plenty. For instance, Busse and Spielmann (2006) explored the international linkage between gender wage inequality and trade flow for 92 developed and developing economies using cross-sectional data. The study found that gender wage inequality positively associated with comparative advantages in labor-intensive goods (that is countries with larger gender wage gap had have higher exports of these goods) and by extension had a positive effect on economic growth while gender inequality in labour force activity rates and educational attainment rates were negatively linked with comparative advantage in labourintensive commodities.

Esteve-Volart (2009) used cross-sectional data for the Indian economy to investigate the effects of gender discrimination in labor markets using an occupational choice model and found that gender discrimination reduced the human capital stock available to the economy and distorted the distribution of entrepreneurial talent across the various occupations. Cuberes and Teignier (2012) studied the effects of gender inequality in selected developing and developed economies labor markets by engaging a model of talent allocation. The study discovered that if all females were excluded from managerial positions, output per worker would decrease by over $10 \%$, and if all females were excluded from the labor force, the loss in income per capita would be almost $40 \%$.

Barro and Lee (2013) studied the 146 economies using cross country data and found a positive correlation between growth of per capita income and initial level of female school attainment after controlling for other factors such as initial per capita income and male school attainment. Cuberes and Teignier (2013) used cross country data for selected countries in the Middle East, North Africa, Europe and Central Asia, to examine the effects of gender inequality in entrepreneurship and labor force participation on aggregate income and productivity using an occupational choice model with heterogeneous agents in entrepreneurial ability. The results of the study show that gender gaps in entrepreneurship negatively affected aggregate productivity, while gender gaps in labor force 
participation diminished per capita income. The results from the simulation also showed that the exclusion of all the women from entrepreneurship would result to a drop in average output per worker by almost $12 \%$ and an exclusion of all the women from the labor force will reduce per capita income by almost $40 \%$.

The study further discovered that gender gaps (inequality) and their entailed income losses are quite comparable across income groups but vary across geographical regions, with a total income loss of $27 \%$ in Middle East and North Africa and a 14\% loss in Europe and Central Asia.

Teignier and Cuberes (2014) examined the quantitative effects of gender gaps in entrepreneurship and labor force participation on aggregate productivity and per capita income using labor market data from the International Labor Organization for 126 countries. The study simulated an occupational choice model with heterogeneous agents in entrepreneurial ability, where agents choose to be workers, self-employed or employers while assuming that the males and females had the same talent distribution. Results from this stimulation showed that gender gaps in entrepreneurship and in female workers' pay negatively affected aggregate productivity, while gender gaps in labor force participation reduced income per capita. In precise terms, if all females were excluded from entrepreneurship, average output per worker would drop by $12 \%$ as the average talent of entrepreneurs would reduce and if all women were excluded from participating in the labor force, per capita income would reduce by $40 \%$. The study also found differentials in the cross-country analyses as gender gaps and their implied income losses vary across geographical regions; it found a total loss in income of 27\% in Middle East and North Africa and a 10\% loss in Europe.

Cuberes and Teignier (2016) examined the quantitative effects of gender gaps on entrepreneurship and workforce participation with the aid of an occupational choice model which accommodated heterogeneous means in entrepreneurial skills. The study discovered that gender gaps in entrepreneurship negatively affect both income and aggregate productivity, since they reduce the entrepreneurs' average talent. Particularly, the expected income loss from excluding $5 \%$ of women is $2.5 \%$, while the loss is $10 \%$ if they are all employers. The results further confirm that gender gaps cause an average income loss of $15 \%$ in the OECD, $40 \%$ of which is due to entrepreneurship gaps. When the model was extended to developing countries, substantial higher losses with significant variation across regions were observed.

Kazandjian, et al, (2016) studied gender equality and economic diversification in selected low-income countries and developing countries for the period 1990 to 2010 using the fixed effect panel data and the instrumental variable generalized method of moments (IV-GMM). The study modeled output/export diversification as a function of gender inequality using the United Nations gender inequality index as well as a low-income and developing country interaction term amongst other structural, institutional and policy variables. The major findings include that gender inequality is negatively and significantly associated with export diversification as lower female to male enrollment ratio is a barrier to human capital development in an economy. Secondly, gender inequality in the labour market restrains the development of new ways of doing things thereby decreasing overall efficiency of the labour force. These findings support the assertion that gender-friendly policies impact positively on output/export diversification.

In line with Agénor and Canuto (2013), Kim, Lee, and Shin (2016) developed a model to test the relationship between gender inequality and growth of the economies. The model which primarily focused on determination of women's time allocation among production for commerce, production subsistent, child rearing, and child education used Asian Economies' micro-level data and found that improving gender equality contributes significantly to economic growth through significant reallocation of females' time and further promotes the accumulation of human capital. Through stimulation, the study also found that the absence of gender inequality will boost aggregate income to about $6.6 \%$ and $14.5 \%$ higher than its benchmark after one and two generations, respectively, and that corresponding per capita income will also increase by $30.6 \%$ and $71.1 \%$ in the hypothetical gender-equality economy as fertility and population expectedly decrease as women participate more freely in labor market activities.

Cavalcanti and Tavares (2016), with a model of endogenous savings, fertility and labour market participation, studied the output cost of gender discrimination in selected developing and developed countries including the Unites States of America and reported that a rise of $50 \%$ in the gender wage gap could lead to a reduction in per capita income by $35 \%$ in the steady state for the US economy. It further found that for several countries, a large fraction of the difference between the country's output and the US output can be ascribed to differences in gender discrimination.

In summary, the extensive review of previous studies on the effect of gender inequality on economic diversification has revealed the paucity of this research in Nigerian economic literature as most of studies conducted for the developing economies were cross-sectional in nature and therefore, did not attend to the country specifics of the Nigerian economy. This study therefore stands in to fill this gap in literature and to make both theoretical and empirical contributions to the debate on gender inequality and economic diversification. 


\section{RESEARCH METHODOLOGY}

\subsection{THEORETICAL FRAMEWORK AND EMPIRICAL MODEL}

The endogenous growth theory forms the theoretical framework for this study because it emphasizes the importance of the type of production in which a country specializes, as the returns to scale as well as the extent of economic diversification depend on the sector (whether primary/extractive - agricultural and mining sectors or secondary manufacturing sector) which produces both the exportable and the output which yields its bulk of fiscal revenue. Structural models of economic development demonstrate that countries develop their output (export) structure from primary commodities (exports) into manufactured commodities (exports) in order to achieve sustained economic growth. Based on the assumption of increasing returns to scale for the manufacturing sector and constant returns to scale for the primary sector, it apparently follows that a country's manufacturing output will grow faster (or slower) than that of the rest of the world if it had an initial comparative advantage in manufacturing (or primary) sector as hypothesized by the Prebisch-Singer Hypothesis.

The endogenous growth model explains that economic progress can be achieved within the system governing the production process instead of by forces operating outside the system as presented by the Solow residual in the neoclassical growth model. They bear some structural resemblance to their neoclassical equivalence, but their most significant structure is in the neglect of the neoclassical assumption of diminishing marginal returns to capital. Most of the endogenous growth models introduce some types of capital like human capital, knowledge and fertility, whose accumulation is not subject to the assumption of diminishing marginal returns. An endogenous growth model of the $A K$ type assumes an economy with a production function which has a constant marginal product of capital and capital as the only factor input.

Specifically,

$Y=a K$

where output $(Y)$ is proportional to the capital stock $(K)$; the marginal product of capital is simply the constant $(a)$. Furthermore, the endogenous growth theory hinges on the notion that there are substantial external returns to capital especially human capital as each new idea (knowledge) makes the next idea possible hence knowledge can grow indefinitely. The new growth theorists believe that research/development and investment in human capital are the keys to economic progress hence Equation 1 may be further expressed as

$$
Y=A K^{\alpha} L^{1-\alpha}
$$

where $(Y)$ is economic progress; $(A)$ is any factor that influences the level of domestic technology, $(K)$ is capital (including material and human aspects) while (L) stands for labour. This model assumes increasing returns to scale and diminishing marginal productivity of factor inputs.

In order to ascertain whether gender inequality is part of the reason for the low economic diversification in Nigeria, this study specified the following general relationship:

$$
Y_{t}=F\left(X_{t}\right)
$$

This general form specifies $\mathrm{X}_{\mathrm{t}}$ as the vector of determinants of economic diversification in Nigeria. Specifically, the econometric form of the model is as follows:

$$
\begin{gathered}
E C O D=\alpha_{0}+L P G D P \alpha_{1}+O P N \alpha_{2}+E X C \alpha_{3}+I N F \alpha_{4}+N A T \alpha_{5}+V U L \alpha_{6}+L A P \alpha_{7}+E M P \alpha_{8} \\
+\mu
\end{gathered}
$$

Equation 4 specifies that economic diversification is a function of per capita income, openness of the economy to trade, official exchange rate, infrastructure available in the country, resource endowment and the variables of focus, gender inequality represented by ratios of vulnerability, labour participation and employer. Data for the study spanned from 1990 to 2016. The choice of the scope of the study is based on data availability. All data for the study were sourced from World Development Indicator (2016).

\subsection{DEFINITION OF VARIABLES}

Income (LPGDP): This captures the economic size of the country. Economic diversification requires financial strength and a resource-rich country like Nigeria has an appreciable lot. However, a resource-dependent country like 
Nigeria most often finds it difficult to diversify, and this brings about a situation known as resource-curse. The income variable is represented by per capita GDP (PGDP) and the a priori expectation is indeterminate. The variable is measured in current United States of American Dollars.

Openness to Trade (OPN): This measures the extent of importance of international trade and financial inflows into an economy and is measured as trade as a percent of GDP. The expectation is that the more open a country is, the greater the extent of diversification.

Exchange Rate (EXC): this is the official rate at which the Naira exchanges for one US dollars. For a country that enjoys inflow of foreign exchange as a result of exports of natural resource, the naira is expected be more expensive relative to other foreign currencies. This reduces Nigeria's competitiveness and further reduces economic diversification. On the other hand, exchange rate depreciation is expected to increase the demand for Nigerian goods and increase diversification. Therefore, the a priori expectation for exchange rate is indeterminate.

Infrastructure (INF): The ability of a country to produce both for local consumption and for exports is hinged on the extent of capital accumulation, notably the quality of infrastructure. This study captured this using electric power consumption ( $\mathrm{kWh}$ per capita). This represents the level and state of infrastructure in Nigeria. We anticipate a positive impact on economic diversification.

Resource Endowment (NAT): Natural resources, such as crude oil, have huge on an economy. When these resources are utilized efficiently, it impacts positively otherwise, negatively thereby giving rise to the resource-curse phenomenon. We capture resource endowment with natural resource as a percentage of GDP and we expect a negative impact on diversification.

Gender Inequality: This is the variable in focus and there are lots of measures to capture gender inequality. However, due to unavailability of complete data for gender inequality index for Nigeria, this study approved the following as measures for gender inequality:

a. Ratio of female to male in vulnerable employment (VUL): This was calculated by dividing percentage of female in vulnerable employment by percentage of male in vulnerable employment. Vulnerable employment is the proportion of self-employed without employees (own account worker) unpaid family workers (contributing family workers) in total employment. This ratio falls between zero and one. A value of one means that there is parity in vulnerable employment between females and males. A value less than one means that females in vulnerable employment are lower than males in vulnerable employment and a value greater than one means that females in vulnerable unemployment are higher than males in vulnerable employment. We expect that increase in the ratio of vulnerability would reduce economic diversification.

b. Ratio of female to male labour force participation rate (LAP): Labor force participation rate is the proportion of the population ages 15 and older that is economically active (the labour force of the country). This is calculated by dividing the female labour force participation rate by that of the males. This ratio falls between zero and one. A value of one means that there is parity in labour participation between females and males. A value less than one shows that female labour participation is lower than male labour participation while that greater than one shows that female labour participation is higher than that of the males. We expect that increase in ratio of labour participation will engender economic diversification.

c. Ratio of females to males who are self-employed (EMP): This captures the ratio of females to males who work on their own account or with few partners/employees or are self-employed. Parity between men and women exists if the value of this ratio is one. A value less than one means that self-employed females are less than their male counterparts while a value greater than one means that self-employed female are greater than their male counterparts. We expect that as the value tends towards unity, economic diversification increases.

A more gender-equal society will make women have more access to education, health, economic and political opportunities. It will also lead to a more diversified economy as more women are empowered in economic activities. Economic Diversification (ECO): Our calculation of economic diversification was based on HerfindahlHirschman $(\mathrm{H})$ approach. ECO is computed as the sum of the squares of the sectoral shares of the economy's output. Supposing that $\mathrm{N}$ sectors share all economic activities, each one with a contribution $k_{i}$ and sectoral share

$$
S_{i}=\frac{k_{i}}{\sum_{j=1}^{N} k_{j}}
$$

Then the DI can be expressed as: 


$$
D I=\sum_{i=1}^{N} S^{2}
$$

Since ECO computed using Herfindahl-Hirschman (H) procedure can range from $1 / N$ to one, we place a restriction such that it ranges from zero to one:

$$
D I^{*}=\frac{D I-1 / N}{1-1 / N} \text { for } \mathrm{N}>1 .
$$

$\mathrm{H}^{*}$ ranges from 0 to 1 .

According to Tauer (1992) cited in Dimnwobi et al (2017), a DI* of 0.00 and 0.01 , higher than 0.01 but below 0.15 , between 0.15 to 0.25 and above 0.25 indicate a highly diversified economy, a bit diversified economy, reasonably diversified economy and an undiversified economy respectively.

\section{RESULT ANALYSIS AND DISCUSSION OF MAJOR FINDINGS}

\subsection{TESTS AND RESULTS}

Data analysis for this study was performed using E-Views 9.0 econometric software. We began by conducting Augmented Dickey-Fuller (ADF) unit root tests for all the variables of the study to check the stationarity or otherwise of these variables. The outcome as presented on Table 1 show that Since all the variables were found to be stationary at first difference, we conducted cointegration test using Engle-Granger cointegration method to test the long run relationship among these variables. The result is presented in Table 2.

Table 1:

Augmented Dickey Fuller Test

\begin{tabular}{llllll}
\hline Variable & ADF Test Statistic & $\mathbf{1 \%}$ Critical Value & $\mathbf{5 \%}$ Critical Value & $\mathbf{1 0 \%}$ Critical Value & Remarks \\
\hline ECOD & -6.264405 & -4.374307 & -3.603302 & -3.238054 & $\mathrm{I}(1)$ \\
INF & -6.043117 & -4.374307 & -3.603302 & -3.238054 & $\mathrm{I}(1)$ \\
EXC & -3.318182 & -4.374307 & -3.603302 & -3.238054 & $\mathrm{I}(1)$ \\
OPN & -7.153023 & -3.724070 & -2.986225 & -2.63604 & $\mathrm{I}(1)$ \\
LPGDP & -3.63461 & -4.374307 & -3.603302 & -3.238054 & $\mathrm{I}(1)$ \\
NAT & -7.599912 & -4.394309 & -3.612199 & -3.243079 & $\mathrm{I}(1)$ \\
LAP & -6.977229 & -4.374307 & -3.603302 & -3.238054 & $\mathrm{I}(1)$ \\
VUL & -4.680991 & -4.374307 & -3.603302 & -3.238054 & $\mathrm{I}(1)$ \\
EMP & -4.338752 & -4.416345 & -3.622033 & -3.248592 & $\mathrm{I}(1)$ \\
ECM & -3.966531 & -4.356068 & -3.595026 & -3.233456 & $\mathrm{I}(0)$ \\
\hline
\end{tabular}

Source: Authors' computation using E-Views 9.0

Table 2:

Long Run Result

Dependent Variable: ECOD

Method: Least Squares

Date: 06/27/18 Time: 20:52

Sample: 19902016

Included observations: 27

\begin{tabular}{crrrr}
\hline Variable & Coefficient & Std. Error & t-Statistic & Prob. \\
\hline INF & -0.000783 & 0.000377 & -2.077175 & 0.0516 \\
EXC & 0.000173 & 0.000149 & 1.157314 & 0.2615 \\
OPN & 0.000714 & 0.000441 & 1.616387 & 0.1225
\end{tabular}




\begin{tabular}{crrrr} 
LPGDP & 0.090888 & 0.083139 & 1.093205 & 0.2880 \\
NAT & 0.001782 & 0.000628 & 2.838506 & 0.0105 \\
LAP & -0.595274 & 0.468329 & -1.271060 & 0.2190 \\
VUL & 0.263333 & 0.962798 & 0.273508 & 0.7874 \\
EMP & -0.117404 & 0.282083 & -0.416204 & 0.6819 \\
\hline & 0.802261 & Mean dependent var & & 0.930282 \\
-squared & 0.729410 & S.D. dependent var & & 0.038533 \\
ession & 0.020044 & Akaike info criterion & & -4.740560 \\
d resid & 0.007634 & Schwarz criterion & & -4.356608 \\
od & 71.99756 & Hannan-Quinn criter. & & -4.626391 \\
\hline son stat & 1.475346 & & \\
\hline
\end{tabular}

Source: Authors' computation using E-Views 9.0

The long run regression results show that coefficient of determination $\mathrm{R}^{2}$ of is 0.802261 while the adjusted $\mathrm{R}^{2}$ is 0.729410 . This means that the independent variables on the average accounted for about $73 \%$ changes in economic diversification and therefore, we can confidently say that the estimated model has a strong goodness of fit. The residual out of the results of the long run equation was generated. This residual, which is the error correction term was found to have unit root at level form (see Table 1). This showed that these variables are cointegrated and that a long run relationship truly existed among them. We proceeded to run an error correction model with the lagged variable of the error term and first differenced form of the other variables, and this enabled us to get the short run relationship which is shown on Table 3.

Table 3:

Error Correction Model Result

Dependent Variable: D(ECOD)

Method: Least Squares

Date: 06/27/18 Time: 21:05

Sample (adjusted): 19912016

Included observations: 26 after adjustments

\begin{tabular}{rrrrr}
\hline Variable & Coefficient & Std. Error & t-Statistic & Prob. \\
\hline D(INF) & -0.000923 & 0.000425 & -2.171101 & 0.0444 \\
D(EXC) & 0.000294 & 0.000189 & 1.558946 & 0.1374 \\
D(OPN) & 0.000533 & 0.000396 & 1.343383 & 0.1968 \\
D(LPGDP) & 0.172668 & 0.083076 & 2.078429 & 0.0531 \\
D(NAT) & 0.001679 & 0.000494 & 3.402354 & 0.0034 \\
D(LAP) & -0.582018 & 0.435901 & -1.335206 & 0.1994 \\
D(VUL) & -0.562374 & 0.953481 & -0.589812 & 0.5631 \\
D(EMP) & 0.171919 & 0.320943 & 0.535668 & 0.5991 \\
ECM(-1) & -0.728584 & 0.301199 & -2.418948 & 0.0271 \\
\hline R-squared & 0.664933 & Mean dependent var & & -0.003194 \\
Adjusted R-squared & 0.507255 & S.D. dependent var & & 0.026426 \\
S.E. of regression & 0.018550 & Akaike info criterion & & -4.869270 \\
Sum squared resid & 0.005850 & Schwarz criterion & & -4.433775 \\
Log likelihood & 72.30050 & Hannan-Quinn criter. & & -4.743863
\end{tabular}


Source: Authors' computation using E-Views 9.0

The error correction term is negatively signed and significant. The result shows that the speed of adjustment to any distortion in the economy is about $73 \%$. The Durbin-Watson statistic shows the absence of autocorrelation.

\subsection{DISCUSSION OF MAJOR FINDINGS}

The signs and significance level of the coefficients of the variables varied according to time periods. While the coefficients of infrastructure, exchange rate, openness, income, resource endowment and labour participation maintained their respective signs in the two time periods; the signs for coefficients of ratios of vulnerable employment and self-employment changed. In the long run, vulnerable employment was positive and negative in the long run and short run respectively. On the other hand, the coefficients of ratio of self-employment were negative and positive in the long run and short run respectively. The significance level of income per capita was insignificant in the long run but significant in the short run. The discussions for each variable are as follows:

Coefficient of the ratio of female to male in vulnerable employment (VUL): Although the short run result is contradictory, the coefficient of the ratio of female to male vulnerable employment is positive but not significant in the long run. This means that as the ratio increases, the number of females in vulnerable employment is higher than males in vulnerable employment and this increases the diversification index. In other words, as the number of females in vulnerable employment increases, economic diversification increases. We had expected that an increase in the ratio of vulnerability would reduce economic diversification.

Ratio of female to male labour force participation rate (LAP): Our long run result found a negative coefficient for this variable. This means that as the ratio of female to male labour force participation rate increases, (that is increased female labour participation) the economic diversification index reduces. This is obtainable for the two time periods and it shows that participation of women in Nigeria's labour improves our stance at economic diversification.

Ratio of female to male self-employment (EMP): Our findings show a negative coefficient for the ratio of female self-employment. This follows that as the female self-employment increases, the economic diversification index decreases in the long run. However, we found that in the short run, increase in the number of female employers increases economic diversification in Nigeria.

Infrastructure: The sign of the coefficient of infrastructure in the time periods were negative and significant. This means that improvement in infrastructure reduces the diversification index. Thus, improved infrastructural base increases the level of economic diversification and this result did not contradict our a priori expectation.

Exchange Rate: Our finding revealed that an increase in exchange rate (depreciation) increases the diversification index. That is, when the naira/dollar exchange rate depreciates, the diversification index increases which signifies a reduction in economic diversification. Nigeria enjoys large inflow of petro-dollar, thereby causing appreciation of the currency. In addition, because we do not have adequate goods that are of export quality, the nation, most often does not take advantage of depreciation of the currency.

Openness to Trade: The study found that as the extent of openness to trade increases, the diversification index also increases signifying a reduction in the level of economic diversification. Thus, openness and increased international trade does not aid Nigeria's diversification drive. Our domestically produced commodities may be displaced by the imported commodities and this further hamper our chances at economic diversification.

Income: this study found a proof that the size of the Nigerian economy impacts negatively on its economic diversification drive since the sign of the coefficient of income was positive. This means that increases in income positively impacts on importation thereby signifying a reduction in the diversification process. This is a support for resource-curse syndrome currently plaguing the Nigerian economy.

Resource Endowment: Another proof of Nigeria's resource-curse syndrome is evidenced in the positive coefficient of contributions of natural resources variable. This means that an increase in the contributions of natural resource to Nigeria's GDP increases, the diversification index increases thereby signifying lowered potentials for economic diversification.

\section{CONCLUSION AND RECOMMENDATIONS}

Our study found that the quality of infrastructure is very important for economic diversification because its impact was significant in both long run and short run. The study also found the existence of resource-curse - the obvious 
neglect of the non-oil sector and concentration of attention on the oil sector is the major cause of the insignificant speed in Nigeria's diversification process. This study found that the existing gender inequality has negative effect on the drive to diversify the economy by reducing the potential pool of human capital and promoting gaps in opportunities. Thus, for opportunities for economic diversification to increase in Nigeria, more programmes on female self-employment, increased ratio of female to male labour force participation rate and a reduction in the ratio of female to male in vulnerable employment should be included in policy formulaions. The results corroborate earlier findings by Cuberes and Teignierz (2013, 2015); Kazandjian, et al (2016), whose separate studies found that gender gaps in favour of men negatively affect national income, export, and aggregate productivity.

Gender inequality in access to productive resources reduces the use of such resources and thereby creates unemployment. More importantly, unequal access to education, health and technology make women less equipped to take on different roles in the production process. Gender inequality is a cause as well as a consequence of persistent poverty in Nigeria and poverty has been identified as a constraint to economic growth. The existences of these gaps lower the level and speed of economic diversification. Thus, the imperatives of harnessing the unutilized capability of women folk hitherto hidden and shrouded by persistent and endemic gender inequality is now. The drop-in oil prices since 2014 that triggered the diminishing growth prospects of leading macroeconomic variables and imposed significant macroeconomic adjustment needs on the Nigerian economy, calls for employment of all underutilized resources, including the female gender. Genuine efforts to diversify the economy must involve the vigorous and virile human resource capability of women.

A good number of researches have shown that the female gender suffers from a lot of inequalities. These inequalities come in various forms which include inequality in access to health, education, economic resources and job opportunities. It also includes gender wage gap and lack of control over self and productive resources. The consequences of this are many and dire. They affect the individual, her family, her immediate community and the Nigerian economy at large. These finding confirms Jayasinghe and Nobel (nd) who found that higher levels of gender equality are associated with greater export diversity and quality - a difference of up to $72 \%$ on average for export diversity and $42 \%$ on average for export quality. There are various channels through which increased participation of women in economic activities can help widen the economic base of a country. For instance, gender equality ensures that women's disproportionate unpaid work is recognized, reduced and redistributed so that they are now more and better capable of contributing to economic growth and diversification. In addition, gender equality ensures that decent jobs are created for all, irrespective of gender, creating a better work environment that will increase productivity.

Creating a balance between men and women is also important for building human capital for the future and there by sustaining economic diversification. Empirical evidence has shown that an empowered woman is better able to raise more educated and healthier children. The paper therefore recommends that efforts should be sustained that totally remove or reduce to their barest minimum all patriarchal tendencies that exploit the female gender and place them at unequal gender relations in Nigeria. It is also recommended that social institutions such as social protection mechanisms should be entrenched further as an avenue to reduce the vulnerabilities faced by women in Nigeria. In addition, deliberate government policy aimed to increase the provision of infrastructure and upgrade existing ones targeted especially towards the advancement and expansion of sectoral choices is imperative. In this regard, various tiers of government - local, state, and federal - should take advantage and develop other sectors of the economy especially where their comparative advantage is higher. There is urgent need to invest heavily in power and ensure uninterrupted supply of electricity.

\section{REFERENCES}

Aina, O. I. (2012). Two halves make a whole: Gender at the crossroads of the Nigerian development agenda, 1-67. http://localhost:8080/xmlui/handle/123456789/3583

Agénor, P. R., \& Canuto, O. (2015). Gender equality and economic growth in Brazil: a long-run analysis. Journal of Macroeconomics, 43, 155-172.

Barro, R. J., \& Lee, J. W. (2013). A new data set of educational attainment in the world, 1950-2010. Journal of development economics, 104, 184-198.

BÖSERUP, E. (1970). Women's Role in Economic Development, Nueva York, St..

Braunstein, E. (2011). Gender Equality and Economic Growth. Fe Dergi, 3, 54-67.

Busse, M., \& Spielmann, C. (2006). Gender inequality and trade. Review of International Economics, 14(3), 362379.

Cavalcanti, T., \& Tavares, J. (2016). The Output Cost of Gender Discrimination: A Model-based Macroeconomics Estimate. The Economic Journal, 126(590), 109-134. 
Cuberes, D. and Teignier, M. (2012) Gender gaps in the labor market and aggregate productivity. Working Paper. Department of Economics, University of Sheffield ISSN 1749-8368

Cuberes, D and Teignier, M, (2013) Gender Gaps in the Labor Market and Aggregate Productivity.Unpublished Manuscript, Department of Economics, University of Sheffield, United Kingdom,

Cuberes, D., \& Teignier, M. (2016). Aggregate effects of gender gaps in the labor market: A quantitative estimate. Journal of Human Capital, 10(1), 1-32.

Cuddington, J. T., Ludema, R., \& Jayasuriya, S. A. (2002). Prebisch-singer redux (No. 1506-2016-130803).

Dimnwobi, S.K., Nwokoye, E.S., Ekesiobi, C.S., and Igbanugo, C.I. (2017) Transportation infrastructure and diversification of Nigeria's Economy: Implications for the Developmental State. Nigerian Journal of Economics and Social Studies, 57(3): 309-331/

Economy Watch (2010-2016).http://www.economywatch.com/economic statistics/Nigeria/GDP Current Prices National Currency/ Accessed on 13/08/2018.

Esteve-Volart, B. (2004). Gender discrimination and growth: Theory and evidence from India. Vol. 42, 1-68.

Galor, O., \& Weil, D. N. (1996). 0The Gender Gap, Fertility and Growth1. American Economic Review, 85(3), $374-87$

Goldin, C. (1992). Understanding the gender gap: An economic history of American women. OUP Catalogue.

International Monetary Fund, (2016). Time for a Policy Reset. Regional Economic Outlook: Sub-Saharan African. Washington DC:

International Planned Parenthood Federation, (2017) Gender Equality Strategy and Implementation Plan. www.ippf.org/resources/ippf-2017-gender-equality, Accessed 1st July. 2018

Kazandjian, R., Kolovich, L., Kochhar, K., \& Newiak, M. (2019). Gender equality and economic diversification. Social Sciences, 8(4), 118.

Kim, J., Lee, J. W., \& Shin, K. (2016). A model of gender inequality and economic growth. Asian Development Bank Economics Working Paper Series, (475).

Metu, A., \& Nwokoye, E. (2015). Investigating Impediments to Accessing Finance for Female Micro Entrepreneurs in Awka, Nigeria. International Journal of Banking, Finance, Management \& Development Studies, 1(15), 257-274.

Prebisch, R., \& Unies, N. (1950). The Economic Development of Latin America, and Its Principal Problems [by Pr. Raul Prebisch, October 1949]. NY.

Raffer, K., \& Singer, H. W. (2002). The economic North-South divide: six decades of unequal development. Edward Elgar Publishing.

Singer, H. W. (1975). The distribution of gains between investing and borrowing countries. In The Strategy of International Development (pp. 43-57). Palgrave Macmillan, London.

Teignier, M., \& Cuberes, D. (2014). Aggregate costs of gender gaps in the labor market: A quantitative estimate. 